\title{
Gender Differentials in Reading Behaviour Among Children
}

\author{
Rita Rani , Raj Pathania and Shubhangna Sharma \\ Department of Human Development, College of Home Science, CSK, HPKV, \\ Palampur 176 062, Himachal Pradesh, India
}

KEYWORDS Printed media; adolescent; mass media; reading material

\begin{abstract}
The present study was undertaken with the objective to examine the influence of printed media on children. The present study was conducted in Panchrukhi block of Kangra district of Himachal Pradesh. A total of 100 children (50 males and 50 females) in the age group of 6-18 years were randomly selected for the study. The findings indicated that more males as compared to females spent less than one hour in reading newspaper and magazine and preferred to study magazines related to general knowledge, and also were interested in studying books related to crime and detection while females were studying story and drama books. The significant association was observed between males and females on variables like time spent on reading newspaper, type of magazines and books preferred.
\end{abstract}

\section{INTRODUCTION}

Printed media also play important role in disseminating and imparting the knowledge. It has brought out tremendous change in the life style of people. There are various types of printed media like books, comics, magazines and newspapers. Children first begin to read newspaper for the comic strips. Gradually as a result of their studies, they begin to read the news and editorials.

Books and newspapers give the children new information and knowledge, which is essential for their academic work. Punhani (1995) reported that magazines provide the greatest share of recreational reading. The print media can also be used for creating awareness about the right of the child. Girls enjoyed fashion magazine and short stories, while boys read sports magazines and adventurous stories. Reading of books, newspapers, magazines, and even comics give the knowledge and enhance the new information, and creativity. Books can meet the social needs of the children by helping them to understand people and social situations and develop socially approved behaviour. At the same time magazines, books and comics can also distort the values and materials relating to sex, violence and fear can over stimulate and often frighten the children.

Therefore printed media has both positive and negative effects on children. These not only provide new information but also help them enacting the socially acceptable values and behaviour. Too much dependence on printed media also cut them socially. The present study was undertaken with the objective to examine the reading behaviour of male and female children.

\section{MATERIAL AND METHODS}

The study was conducted in the Panchrukhi block of Kangra District of Himachal Pradesh. From the selected block 100 children (50 males and 50 females) in the age group of 6-18 years were randomly selected. The children irrespective of caste, creed, and economic status were selected. A self structured interview schedule was developed keeping in view the objectives of the present study and to get the information from respondents regarding influence of books and magazines on children. After the collection of data the information gathered was tabulated. The statistical tools applied were percentages and chisquare test.

\section{RESULTS AND DISCUSSION}

Table 1 presents number of hours spent on newspaper reading by girls and boys. It can be seen from the table that there were only 18 per cent and 22 per cent female respondents who spent more than two hours in newspaper reading. About half of the respondents spent less than one hour.Only 16 per cent males and 19 per cent females spent 1-2 hrs in reading newspapers and magazines. Now days children spent their leisure time in watching television or on computers. They were not much interested in newspapers etc. The chi-square test showed significant association between newspaper reading and sex of the respondents. Contrary to the study of Hurlock (1978) reported that as child approach puberty, they often spent more time in reading newspaper than books.

There were various types of magazines avail- 
able in the market (Table 2). Most of the males and females respondents i.e., 38 per cent each preferred to study general knowledge and political magazines as children were future conscious today. Since children were imitator and attracted towards new fashion trends therefore many children also studied fashion magazines.

Table 1: Time spent in reading newspaper and magazine

\begin{tabular}{lccr}
\hline Time & Male & Female & Total \\
\hline Less than 1 hour & $25(50)$ & $20(40)$ & $45(45)$ \\
$\quad 1-2$ hours & $16(32)$ & $19(38)$ & $35(35)$ \\
More than 2 hours & $9(18)$ & $11(22)$ & $20(20)$ \\
\hline Total & 50 & 50 & 100 \\
\hline
\end{tabular}

$\doteqdot^{2} \mathrm{Cal}=18.78^{*}$ Figures in parenthesis indicate per cent

One fifth males and 30 per cent females preferred fashion magazines About $1 / 5^{\text {th }}$ of the male and female respondents studied film and sports magazines. Boys enjoyed magazines dealing with popular science with adventure while girls preferred those, which were related to romance, beauty, clothes and glamour.

Table 2: Type of magazine preferred by respondents

\begin{tabular}{lcrr}
\hline Magazine & Male & Female & Total \\
\hline Film Magazine & $5(10)$ & $6(12)$ & $11(11)$ \\
Sports magazine & $10(20)$ & $5(10)$ & $15(15)$ \\
Fashion magazine & $10(20)$ & $15(30)$ & $25(25)$ \\
General Awareness & $19(38)$ & $5(10)$ & $24(24)$ \\
Political magazine & $6(12)$ & $19(38)$ & $25(25)$ \\
\hline Total & 50 & 50 & 100 \\
\hline${ }^{2} \mathrm{Cal}=17.68 *$ & Figures & in parenthesis indicate per cent
\end{tabular}

The newspapers are not very popular media among the children. But children enjoy comics, film reviews and sports section and take less interest in community, national and international affairs. Table 3 indicates that maximum number of male respondents i.e. 40 per cent and 24 per cent females read international affairs in news papers, followed by 20 per cent males and 12 per cent females who studied political and social section, 16 per cent males and 14 per cent females enjoyed reading sports section. As boys were extrovert and they had explore more things for the future then girls. Only 10 per cent males, 30 per cent females and 14 per cent males, 20 per cent females were interested in art and literature and film reviews respectively. Both males and female respondents had different interests in various issues of newspaper sections. As boys are more extroverts then girls and they have more interested
Table 3: Section of newspaper most liked by respondents

\begin{tabular}{lcrr}
\hline Section of Newspaper & Male & Female & Total \\
\hline International affairs & $20(40)$ & $12(24)$ & $32(32)$ \\
Politics/Social issues & $10(20)$ & $6(12)$ & $16(16)$ \\
Art and literature & $5(10)$ & $15(30)$ & $20(20)$ \\
Film reviews & $7(14)$ & $10(20)$ & $17(17)$ \\
Sports & $8(16)$ & $7(14)$ & $15(15)$ \\
\hline Total & 50 & 50 & 100
\end{tabular}

$\div \mathrm{Cal}=8.58 \mathrm{NS}$; Figures in parenthesis indicate per cent

in exploring the things. The association between section of newspaper liked and sex of respondents was observed as non significant. Contrary to present study Kuthaila (1979) reported that children preferred advertisements in newspapers and magazines.

Table 4 shows that most of the children (males $42 \%$ and $40 \%$ females) were interested in reading books related to crime and detection and drama / play. While books related to history and religion were liked by 18 per cent.

Table 4: Types of books preferred by respondents

\begin{tabular}{lcrr}
\hline Books & Male & Female & Total \\
\hline Crime and detection & $21(42)$ & $10(20)$ & $31(31)$ \\
Adventure & $6(12)$ & $15(30)$ & $21(21)$ \\
History and Religion & $9(18)$ & $5(10)$ & $14(14)$ \\
Drama/Stories/Play & $14(28)$ & $20(40)$ & $34(34)$ \\
\hline Total & 50 & 50 & 100
\end{tabular}

$\div \mathrm{Cal}=9.92 *$

* Significant at $5 \%$ level; Figures in parenthesis indicate per cent

Males and 10 per cent females. Boys always preferred adventurous things, while girls like to live in fantasies. There was significant association between males and females and type of books preferred. Rau (1982) investigated that girls at every age read more books and magazines than boys because they had fewer recreational opportunities. While Hurlock (1978) reported that media provided reading material for children i.e. books, newspaper and magazine; of than books were the most popular among children of both sexes

\section{CONCLUSION}

It was found that printed media brought out tremendous change in the life style of children. Most of the respondents spent less than one hour in newspaper reading. Moreover, boys preferred magazines related to general awareness, 
while girls were interested in fashion magazines. Maximum males liked to read international affairs and girls preferred art and literature in newspaper section. Magazines, books and newspapers can meet the social needs of the children by helping them to understand people, social situation and develop socially approved behaviour. The preference for books by girls were generally related to drama and stories while, boys preferred books dealt with crime and detection. Therefore, it may be concluded that books and magazines were preferred by children in this electronic world also.

\section{REFERENCES}

Hurlock, E.B. 1978. Child Development. $6^{\text {th }}$ Ed. Tokyo: Mc Graw Hill.

Kuthaiala, B.K.1979. "Exposure of Youth to Adertisements." Journal of Indian Institute of Mass Comunation, 14(3): 1-7.

Punhani, R.1995. "Role of the Media." Social Welfare, 42(5): 7-12.

Rau, C.M.1982. "Role of Media in Developing Countries." Journal of Indian Institute of Mass Communication, 17(1):1-2.

Sarangi, B.N. and A.P. Kanurgo. 1988. "Mass mediaharbinger of Social change." Yojana, 32(18):17-19 